Int.J. Hum. Soc. Dev. Res.

ISSN (P):2521-1439; ISSN (E):2523-4331

Volume 3, № 1, 2019. 7-23

DOI: $10.30546 / 2523-4331.2019 .3 .1 .7$

\title{
FACTORS CONTRIBUTING JOB SATISFACTION AND JOB PERFORMANCE OF NURSES IN THE HEALTHCARE INDUSTRY
}

\section{Mohammad ALI ${ }^{1}$}

Hohai University, Nanjing, China

International University of Business Agriculture and

Technology (IUBAT), Bangladesh

\section{Wang QUN}

Business School, Hohai University, Nanjing, China

(C) The Author(s) 2019

\begin{abstract}
Performance of the human resources' affects the quality of outcome and services for any organization, particularly service organization. Previous studies explored large number of factors influence employee's job satisfaction and job performance. In this study we aimed to analyze the relationship of distributing factors (pay, HRMP, work environment, motivation, and promotion) with nurses' job satisfaction and job performance. Questionnaire with 5-Likert scale was distributed to randomly selected nurses (160) from the 15 different private healthcare institutions from Bangladesh. Hypotheses were tested by using statistical software (SPSS). Correlation and regression analysis showed a significant positive correlation between variables like pay structure, human resource management practice, work environment, motivation, and promotion with both job satisfaction and performance of the nurses. A strong positive correlation has been found between nurses' job satisfaction and job performance. Practical implication and future implication of the research direction have been discussed and recommended accordingly.
\end{abstract}

C2019.All rights reserved

\section{ARTICLE HISTORY}

Received: 21/12/2018

Accepted: 19/03/2019

Published online: 01/04/2019

\section{KEYWORDS}

Healthcare services, nurses, job satisfaction, job performance, work environment

\footnotetext{
${ }^{1}$ Corresponding author
}

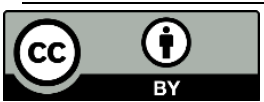

www.ijhsdr.com 


\section{Introduction}

The demand for global healthcare services is experiencing tremendous growth (Smith \& Forgione, 2007). The industry of global healthcare market is now estimated to be worth of some $\$ 10$ tn (£7.7tn; €8.9tn) and its growing faster than GDP in many countries (Organization, 2017). This market extents both the public and the private sectors. Traditional healthcare industries are being reshaped by advances in medical science and technology, increasing specialization in health care and a complex organizational structure. The production and provision of health related goods and services, employment in the health workforce, new technologies, and capital invested in hospitals, clinics, and other health infrastructure affect the prospects for stable economic growth and employment in economies around the world. These effects in turn lead to improvements in population health.

Human resources considered as the backbone of any organization \& plays a vital role for the success of any organization. Employee job performance has always been a major challenge in organizational management and adopting effective ways to motivate employees to achieve and deliver higher job performance as well as increase the organizational competitiveness is the main objective of every business organization (Wu $\&$ Lee, 2011). Hospitals are like any other organization which can't perform without the effective performance of its human resources. Nurses are the largest workforce group in the health care system and their performance affects the quality of healthcare outcome and services. The concept of practice and system of medicine has shifted away from the traditional concept of a noble profession toward a service industry. At present, hospitals have to deal with the issue of service quality (Cheng Lim, Tang, \& Jackson, 1999). Consumers (patients) expect more and more of healthcare providers and demand higher and higher standards of care and service from the hospitals (Downey-Ennis \& Harrington, 2002). Nurses play a significant role in the care of the patient. They are the one who meets the patients, comforts the patients and family, and educates the patients about next steps to better health and recovery. Patient satisfaction has become a frequently used outcome measure of the quality of healthcare delivery. In that sense, satisfaction represents a positive assessment of provided healthcare with respect to the client's goals and expectations (Lochman, 1983). On the other hand, healthcare worker job satisfaction is a very important parameter that influences effectiveness, productivity as well as quality of work, and commitment to work and at the same time on healthcare costs (Gray-Toft \& Anderson, 1985; Janicijevic, Seke, Djokovic, \& Filipovic, 2013). Nurses know how to expand access to care and improve quality at lower cost. 
Job satisfaction can be defined as a universal approach to the perceived emotions based on work experiences (Locke, 1969). Job satisfaction represents a positive or negative attitude towards work and is affected by numerous factors (Seyed Javadin, 2002). Many different studies have shown that there is a great number of factors which can have an impact on healthcare worker job satisfaction, such as: age, gender, level of education, work experience, the way in which work is organized, working conditions, and many others (Bovier \& Perneger, 2003; Haas et al., 2000; Judge, Thoresen, Bono, \& Patton, 2001; Kivimäki, Kalimo, \& Lindstrom, 1994; Verschuren \& Masselink, 1997). Extensive studies have been conducted about job satisfaction, both in the country and abroad. Different researchers focused on different variable affecting job satisfaction and job performance and found mixed results.

Research findings indicated that job satisfaction correlates with, for example, employee motivation and performance (Judge et al., 2001), occupational stress (Nabirye, Brown, Pryor, \& Maples, 2011), communication satisfaction (Pincus, 1986), Working conditions absenteeism (Hackett \& Guion, 1985), organizational citizenship behavior (Organ \& Ryan, 1995), and turnover (Griffeth, Hom, \& Gaertner, 2000).

The previous researchers looked only at a part of this variable therefore this research investigated how the factors (pay, HRMP, working environment, motivation, and promotion) influencing the job satisfaction and their job performance of healthcare workers (nurses) in the private hospitals of Bangladesh.

\section{Literature Review, Conceptual Model and Hypotheses}

The structure of the research model has been developed based on previous relevant literature. The five independent variables pay structure, human resource management practice, working environment, motivation, and promotion, are aligned to the other two dependent variables job satisfaction and job performance as represented in the framework. Furthermore, job performance is used as a variable dependable on job satisfaction. Figure 1 shows the research model and the details description of the variables in the boxes are explained below.

Pay is regarded as the part of the monetary sanction system used by the organization to motivate compliance with its rules and regulations (Mueller \& Price, 1990). For the individual employee, pay is viewed as very important reward or outcome. Meltz \& Marzetti (1998), suggested to use salary differentials as economic incentive to increase nursing job satisfaction and retention (Meltz \& Marzetti, 1988). There is a positive correlation found between pay and workers productivity, effort and job satisfaction. (Lazear, 2000; McCausland, Pouliakas, \& Theodossiou, 2005; Paarsch \& Shearer, 2000).

Int.J. Hum. Soc. Dev. Res. Volume 3, № 1, 2019. 7-23 


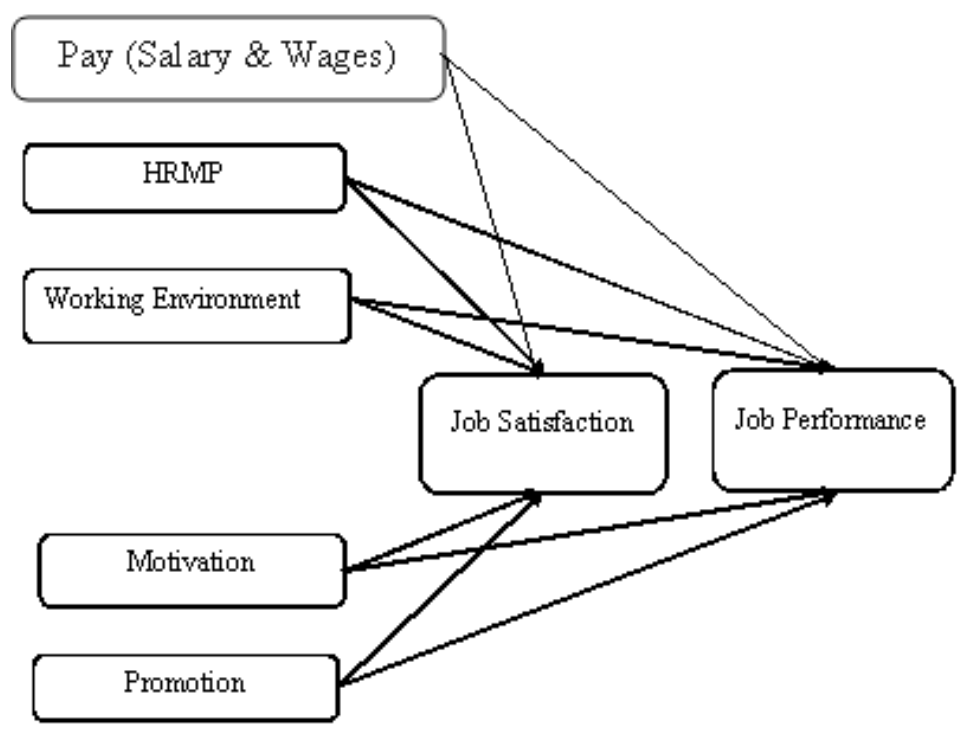

Figure 1. Theoretical Framework

Diriwächter \& Shvartsman (2018) explored that wage increases in small, but regular increments - rather than less frequent but higher increases that add to same amount are the most effective way to motivate employees in the long run (Diriwächter \& Shvartsman, 2018). Judge, Piccolo, Podaskoff, Shaw, and Rich (2010) published a meta-analysis of 86 studies which is related to relationship between pay and job satisfaction (Judge, Piccolo, Podsakoff, Shaw, \& Rich, 2010). In the research they have analyzed 119 correlations and 92 independent samples and reported that within studies, level of pay bears a positive, but quite modest, relationship to job and pay satisfaction. Another interesting finding of the meta-analysis is that employees can be satisfied with pay but dissatisfied with job.

In a cumulated over 39 studies of the relationships of financial incentives to performance quality and quantity (Jenkins Jr, Mitra, Gupta, \& Shaw, 1998) and found financial incentives not related to performance quality.

Following hypotheses were developed related to level of pay on job satisfaction and performance of nurses.

H1: There is a positive correlation between pay and the job satisfaction of Nurses

$\mathrm{H} 2$ : There is a positive correlation between pay and the job performance of Nurses 


\subsection{HRMP (Human resource management practice)}

According to Ruiz-Lozano \& Nieto (2016), Human resource management practices (HRMP) refer to the policies and actions involved in the integral management of employees, including job analysis, recruitment, selection, orientation, compensation, performance evaluation, training, development and industrial relations (Ruiz-Lozano \& Nieto, 2016). Hofstede said HRMP constitute the visible side of the organizational culture, in other words, actions that impart identity to the companies (Hofstede). Different authors have reported that HRMP tend to increase loyalty, organization citizenship behaviors, and job satisfaction (Campbell, Perry, Maertz Jr, Allen, \& Griffeth, 2013; Carlson, Ferguson, Kacmar, Grzywacz, \& Whitten, 2011; Kossek, Baltes, \& Matthews, 2011).

The impact of some HRMP on employee engagement, well-being, and performance is known but their impact on job satisfaction is largely undiscovered (Kehoe \& Wright, 2013), (Saridakis, Muñoz Torres, \& Johnstone, 2013).

Following hypotheses were offered related to HRMP on job satisfaction and performance of nurses.

H3: There is a positive correlation between HRMP on the job satisfaction of Nurses

$\mathrm{H} 4$ : There is a positive correlation between HRMP on the job performance of Nurses

\subsection{Working Environment}

Work environment in an organization consist of all the aspects which act and react the body and mind of an employee. Work environment can be indicated as the social relation at work place and maintain the relationship between colleague, supervisor and the organization. It describes the neighboring circumstances where employees are working together to enhance productivity (Jain \& Kaur, 2014).

The study result regarding working environment and job performance shows that workload, unfavorable working environment decreases job satisfaction, on the other hand good working environment in an organization increases the degree of job satisfaction (Jain \& Kaur, 2014). Moreover, higher job satisfaction and lower intention to leave were found where work environment complemented the creative environment for jobs (Shalley, Gilson, \& Blum, 2000). 
Following hypotheses were developed related to working environment on job satisfaction and performance of nurses.

H5: There is a correlation between working environment and the job satisfaction of Nurses

H6: There is a correlation between working environment and the job performance of Nurses

\subsection{Motivation}

Motivation is the combination of personal and work characteristics that influence people to perform task in a way that make their organization to achieve its objectives and for people to meet their needs (Van Niekerk, 1987). Motivation involves individual and job characteristics that account for employee job related behavior as well (Schultz, Juran, Boudreau, McClain, \& Thomas, 1998).

Kerschen, Armstrong, \& Hillman (2006), stated that level of employee's job satisfaction are influenced by intrinsic and extrinsic motivating factors (Kerschen, Armstrong, \& Hillman, 2006). Motivation studies mostly focused on employee feeling and emotions that are relevant in understanding job satisfaction (H. Baron, Henley, McGibbon, \& McCarthy, 2002; Fisher, 2000; Roodt, Rieger, \& Sempane, 2002). Other studies concluded that employees who are motivated, competent, and satisfied, they can work better to make their organization more productive(J. N. Baron \& Kreps, 1999; Caligiuri, Lepak, \& Bonache, 2010; Pfeffer \& Villeneuve, 1994).

Following hypotheses were offered related to motivation on job satisfaction and performance of nurses.

H7: There is a positive correlation between motivation and the job satisfaction of Nurses

H8: There is a positive correlation between motivation and the job performance of Nurses

\subsection{Promotion}

Promotion is basically a shifting of employee upward in the hierarchy and that leads to enhancement of responsibility, ranked, and an improved compensation package (Lazear, 1986, 2000). Many researchers stated that job satisfaction is strongly correlated with promotion opportunities and there is a direct and positive association between promotional opportunities and job satisfaction (McCausland et al., 2005). On the other hand Moen \& Rosen (2005), identified pay and job security as significant categories of job satisfaction whereas satisfaction with regards to promotion activities not a major 
factor (Moen \& Rosen, 2005). Only a small number of papers are assessing the influence of promotions on satisfaction of job as a whole (Oettinger, 2001; Paarsch \& Shearer, 2000).

Therefore, following hypotheses are developed which are related to promotion on job satisfaction and performance of nurses.

H9: There is a positive correlation between promotion and the job satisfaction of Nurses

H10: There is a positive correlation between promotion and the job performance of Nurses

\subsection{Job satisfaction and Job performance}

If employees are satisfied, they are more likely to committed to their organization and demonstrates higher level of performance and productivity (Steinhaus \& Perry, 1996), (Cranny, Smith, \& Stone, 1992), (Weiss, 2002).

Job satisfaction has been studied both dependent and independent variable. As an independent variable, job satisfaction explains outcomes such as performance, absenteeism, and turnover (Podsakoff \& Williams, 1986), (Cranny et al., 1992), (Nasurdin, Ramayah, \& Osman, 2006). In this study we examine job satisfaction as both dependent and independent variable. As independent variable it explains the outcome of nurses' job performance. And as dependent variable affected by number of factors including pay, human resource management practice (HRMP), work environment, motivation, promotion and workplace stress.

We developed the following hypotheses related job satisfaction and performance of nurses.

H11: There is a positive correlation between job satisfaction and performance of nurses

\section{Research Methodology}

The prime objective of this study is to examine the relationship between the factors (pay, human resource management practice, working environment, motivation, and promotion) and job satisfaction and how it leads to the job performance the nurses. The study has adopted quantitative method. 160 respondent (nurses) were selected randomly from 15 different private healthcare institutions from Bangladesh. In order to develop meaningful result, this research used statistical techniques. All the hypotheses have been verified by the collection and investigation of quantitative data retrieved from the applicable respondents to create causal relationship among the variables. A numerical approach is appropriate for this study to control biases, decrease errors, and conduct the analysis. 
This study uses cross-sectional survey design. Five Likert scales are used for research questions. Another advantages of this research is respondent may feel relaxed to answer to the sensitive nature of the questions rather than face to face interview (Rubin \& Babbie, 2005). SPSS software has been used to test the Hypotheses.

\section{Results and Discussion}

\subsection{Normality Tests}

Normality test has been done by analyzing kurtosis, skewness. George \& Mallery (2010) indicated that values for kurtosis and skewness between -2 to +2 are acceptable to prove the normal distribution (George \& Mallery, 2010). The variables were distributed normally as Skewness and Kurtosis were well in the range -2 to +2 .

Table 1 presents the descriptive statistics such as mean values, standard deviation, and skewness, and kurtosis of the variables.

\section{Table 1. Descriptive Statistics}

\begin{tabular}{|l|l|l|l|l|}
\hline \multicolumn{1}{|c|}{ Variables } & Mean & S.D & Skewness & Kurtosis \\
\hline Payment & 3.9719 & .85781 & -.650 & .435 \\
\hline HRMP & 3.7172 & .74296 & .112 & -.829 \\
\hline Working Environment & 3.9016 & .62136 & -.163 & -1.082 \\
\hline Motivation & 3.7906 & .72462 & -.490 & .700 \\
\hline \multicolumn{1}{|c|}{ Promotion } & 3.9156 & .75125 & -.312 & -.532 \\
\hline Job Satisfaction & 3.9438 & .63193 & -.060 & -.949 \\
\hline Job Performance & 3.8328 & .67042 & -.528 & .406 \\
\hline
\end{tabular}

Table 2 signifies the correlation between nurses' perception of (pay, human resource management practice, working environment, motivation, and promotion) with their job satisfaction and job performance.

Table 2. Correlation Matrix

\begin{tabular}{|l|l|l|r|r|r|r|}
\hline & \multicolumn{1}{|c|}{1} & \multicolumn{1}{|c|}{2} & 3 & 4 & 5 & 6 \\
\hline Payment & \multicolumn{1}{|c|}{1} & & & & & \\
\hline HRMP & .678 & 1 & & & & \\
\hline Working Environment & .605 & .630 & 1 & & & \\
\hline Motivation & .742 & .679 & .747 & 1 & & \\
\hline Promotion & .799 & .575 & .710 & .831 & 1 & \\
\hline Nurses' Job Satisfaction & .528 & .552 & .931 & .742 & .729 & 1 \\
\hline
\end{tabular}




\begin{tabular}{|ll|l|l|l|l|l|l|}
\hline $\begin{array}{l}\text { Nurses' Job } \\
\text { Performance }\end{array}$ & .785 & .728 & .806 & .936 & .849 & .735 \\
\hline
\end{tabular}

Correlation matrix identifies that payment has a strong positive relationship with nurses' job satisfaction $(r=0.528, p<0.05)$ and job performance $(r=0.785, p<0.05)$. Similarly human resource management practice (HRMP) has a significant positive correlation with nurses' job satisfaction $(\mathrm{r}=0.552, \mathrm{p}<0.05)$ and job performance $(\mathrm{r}=0.728, \mathrm{p}<0.05)$. Working environment has a highly significant correlation with nurses' job satisfaction $(\mathrm{r}=0.931, \mathrm{p}<0.05)$ and job performance $(\mathrm{r}=0.806, \mathrm{p}<0.05)$. Another strongly positive correlation has been found between motivation with nurses' job satisfaction $(r=0.742, p<0.05)$ and job performance $(r=0.936, p<0.05)$. Promotion has a significant correlation with nurses' job satisfaction $(r=0.729, p<0.05)$ and job performance $(\mathrm{r}=0.849, \mathrm{p}<0.05)$ as well. A highly significant correlation has been found between nurses job satisfaction and job performance $(r=0.735, p<0.05)$

\subsection{Regression Analysis}

A regression analysis was conducted to examine the hypothesized relationship between independent and dependent variables. Simple linear regression analysis is applied in order to explore the effect of independent variables on dependent variables. Table 3 shows the regression analysis of Hypotheses 1 to 13.

Table 3. Regression Analysis

\begin{tabular}{|c|c|c|c|c|c|c|}
\hline Hypotheses & Variables & B & $\mathrm{SE}$ & $\beta$ & $\mathrm{t}$ & sig \\
\hline \multirow{2}{*}{$\begin{array}{l}\text { H1 Payment With Job } \\
\text { Satisfaction }\end{array}$} & Constant & 2.399 & .202 & & 11.864 & .000 \\
\hline & PWJS & .389 & .050 & .528 & 7.812 & .000 \\
\hline \multirow{2}{*}{$\begin{array}{l}\text { H2 Payment With Job } \\
\text { Performance }\end{array}$} & Constant & 1.397 & .157 & & 8.921 & .000 \\
\hline & PWJP & .613 & .039 & .785 & 15.909 & .000 \\
\hline \multirow{2}{*}{$\begin{array}{l}\text { H3 HRMP With Job } \\
\text { Satisfaction }\end{array}$} & Constant & 2.199 & .214 & & 10.280 & .000 \\
\hline & HRMPWJS & .469 & .056 & .552 & 8.321 & .000 \\
\hline \multirow{2}{*}{$\begin{array}{l}\text { H4 HRMP With Job } \\
\text { Performance }\end{array}$} & Constant & 1.390 & .185 & & 7.454 & .000 \\
\hline & HRMPWJP & .657 & .049 & .728 & 13.362 & .000 \\
\hline \multirow{2}{*}{$\begin{array}{l}\text { H5 Working } \\
\text { Environment With Job } \\
\text { Satisfaction }\end{array}$} & Constant & .250 & .117 & & 2.142 & .034 \\
\hline & WEWJS & .947 & .030 & .931 & 32.020 & .000 \\
\hline \multirow{2}{*}{$\begin{array}{l}\text { H6 Working } \\
\text { Environment With Job } \\
\text { Performance }\end{array}$} & Constant & .441 & .201 & & 2.196 & .030 \\
\hline & WEWJP & .869 & .051 & .806 & 17.099 & .000 \\
\hline
\end{tabular}




\begin{tabular}{|l|l|l|l|l|l|l|}
\hline \multirow{2}{*}{$\begin{array}{l}\text { Hob Motivation With } \\
\text { Jobfaction }\end{array}$} & Constant & 1.492 & .180 & & 8.309 & .000 \\
\cline { 2 - 7 } & MWJS & .647 & .047 & .742 & 13.894 & .000 \\
\hline $\begin{array}{l}\text { H8 Motivation With } \\
\text { Job Performance }\end{array}$ & Constant & .551 & .100 & & 5.501 & .000 \\
\cline { 2 - 7 } & MWJP & 8.66 & .026 & .936 & 33.334 & .000 \\
\hline $\begin{array}{l}\text { H9 Promotion With } \\
\text { Job Satisfaction }\end{array}$ & Constant & 1.544 & .183 & & 8.450 & .000 \\
\cline { 2 - 8 } & PWJS & .613 & .046 & .729 & 13.368 & .000 \\
\hline $\begin{array}{l}\text { H10 Promotion With } \\
\text { Job Performance }\end{array}$ & Constant & .866 & .150 & & 5.791 & .000 \\
\cline { 2 - 7 } & PWJP & .758 & .038 & .849 & 20.201 & .000 \\
\hline $\begin{array}{l}\text { H11 Job Satisfaction } \\
\text { With Job Performance }\end{array}$ & Constant & .759 & .229 & & 3.318 & .001 \\
\cline { 2 - 7 } & JSWJP & .780 & .057 & .735 & 13.616 & .000 \\
\hline
\end{tabular}

The result of the factors contributes to nurses' job satisfaction and job performance shows that all the variables are strongly correlated with nurses' job satisfaction and job performance.

Table 4. Payment and Job Satisfaction Model Summary

\begin{tabular}{|l|l|l|l|l|l|}
\hline $\mathrm{R}$ & $\mathrm{R}^{2}$ & $\mathrm{~F}$ & $\mathrm{Df} 1$ & $\mathrm{Df} 2$ & $\mathrm{p}$ \\
\hline 0.528 & 0.279 & 61.032 & 1 & 158 & 0.000 \\
\hline
\end{tabular}

Table 5. Payment and Job Performance Model Summary

\begin{tabular}{|l|l|l|l|l|l|}
\hline $\mathrm{R}$ & $\mathrm{R}^{2}$ & $\mathrm{~F}$ & $\mathrm{Df} 1$ & $\mathrm{Df} 2$ & $\mathrm{p}$ \\
\hline .785 & .616 & 253.094 & 1 & 158 & 0.000 \\
\hline
\end{tabular}

How much money private hospitals pay to their nurses has a significant correlation with job satisfaction $\left(\beta=.528, \mathrm{R}^{2}=28 \%, \mathrm{p}<0.05\right)$ and job performance $\left(\beta=.785, \mathrm{R}^{2}=\right.$ $62 \%, \mathrm{p}<0.05)$. Thus, we can say that if nurses are satisfied with their salary they will be satisfied with their job and job performance will improve as well. So, hypotheses 1 and 2 have been supported by results.

Table 6. HRMP and Job Satisfaction Model Summary

\begin{tabular}{|l|l|l|r|r|r|}
\hline $\mathrm{R}$ & $\mathrm{R}^{2}$ & $\mathrm{~F}$ & $\mathrm{Df} 1$ & \multicolumn{1}{l|}{ Df2 } & $\mathrm{p}$ \\
\hline 0.552 & 0.305 & 69.233 & 1 & 158 & 0.000 \\
\hline
\end{tabular}


Table 7. HRMP and Job Performance Model Summary

\begin{tabular}{|l|l|l|l|l|l|}
\hline $\mathrm{R}$ & $\mathrm{R}^{2}$ & $\mathrm{~F}$ & $\mathrm{Df} 1$ & $\mathrm{Df} 2$ & $\mathrm{p}$ \\
\hline 0.728 & 0.531 & 178.545 & 1 & 158 & 0.000 \\
\hline
\end{tabular}

Table 6 and 7 shows a significant relationship between Human resource management practice (HRMP) and nurses job satisfaction $\left(\beta=.552, \mathrm{R}^{2}=30 \%, \mathrm{p}<0.05\right)$. Correlation with nurses' job performance shows similar results $\left(\beta=.728, \mathrm{R}^{2}=53 \%, \mathrm{p}<0.05\right)$. That means the better HRMP organization uses the higher job satisfaction and job performance will be. Thus Hypotheses 3 and 4 have been accepted.

Table 8. Working Environment and Job Satisfaction Model Summary

\begin{tabular}{|l|l|l|l|l|l|}
\hline $\mathrm{R}$ & $\mathrm{R}^{2}$ & $\mathrm{~F}$ & $\mathrm{Df} 1$ & $\mathrm{Df} 2$ & $\mathrm{p}$ \\
\hline 0.931 & 0.866 & 1025.268 & 1 & 158 & 0.000 \\
\hline
\end{tabular}

Table 9. Working Environment and Job Performance Model Summary

\begin{tabular}{|l|l|l|l|l|l|}
\hline $\mathrm{R}$ & $\mathrm{R}^{2}$ & $\mathrm{~F}$ & $\mathrm{Df} 1$ & $\mathrm{Df} 2$ & $\mathrm{p}$ \\
\hline 0.806 & 0.649 & 292.383 & 1 & 158 & 0.000 \\
\hline
\end{tabular}

From the result a strong positive correlation has been found between work environment and nurses' job satisfaction $\left(\beta=.931, \mathrm{R}^{2}=86 \%, \mathrm{p}<0.05\right)$ as well as job performance $\left(\beta=.806, \mathrm{R}^{2}=64 \%, \mathrm{p}<0.05\right)$. Which means better working environment in the hospitals can enable nurses to perform better with high job satisfaction. So hypotheses $5 \& 6$ have been well supported by results.

Table 10. Motivation and Job Satisfaction Model Summary

\begin{tabular}{|l|l|l|l|l|l|}
\hline $\mathrm{R}$ & $\mathrm{R}^{2}$ & $\mathrm{~F}$ & Df1 & Df2 & $\mathrm{p}$ \\
\hline 0.742 & 0.550 & 193.042 & 1 & 158 & 0.000 \\
\hline
\end{tabular}

Table 11. Motivation and Job Performance Model Summary

\begin{tabular}{|l|l|l|l|l|l|}
\hline $\mathrm{R}$ & $\mathrm{R}^{2}$ & $\mathrm{~F}$ & $\mathrm{Df} 1$ & $\mathrm{Df} 2$ & $\mathrm{p}$ \\
\hline 0.936 & 0.876 & 1111.128 & 1 & 158 & 0.000 \\
\hline
\end{tabular}


Results shows a strong positive correlation of motivation with nurses' job satisfaction $\left(\beta=.742, \mathrm{R}^{2}=55 \%, \mathrm{p}<0.05\right)$ and job performance $\left(\beta=.936, \mathrm{R}^{2}=87 \%\right.$, $\mathrm{p}<0.05)$. The higher the motivation of employee is the higher the job satisfaction and performance will be. Here hypotheses $7 \& 8$ have been supported by results as well.

Table 12. Promotion and Job Satisfaction Model Summary

\begin{tabular}{|l|l|l|l|l|l|}
\hline $\mathrm{R}$ & $\mathrm{R}^{2}$ & $\mathrm{~F}$ & $\mathrm{Df1}$ & $\mathrm{Df} 2$ & $\mathrm{p}$ \\
\hline 0.729 & 0.531 & 178.699 & 1 & 158 & 0.000 \\
\hline
\end{tabular}

Table 13. Promotion and Job Performance Model Summary

\begin{tabular}{|l|l|l|r|l|l|}
\hline $\mathrm{R}$ & $\mathrm{R}^{2}$ & $\mathrm{~F}$ & $\mathrm{Df} 1$ & $\mathrm{Df} 2$ & $\mathrm{p}$ \\
\hline 0.849 & 0.721 & 408.078 & 1 & 158 & 0.000 \\
\hline
\end{tabular}

Another strong positive correlation have been found between nurses' promotion and job satisfaction $\left(\beta=.729, R^{2}=53 \%, p<0.05\right)$ as well as job performance $\left(\beta=.849, R^{2}=\right.$ $72 \%, \mathrm{p}<0.05)$. So with the promotion the job satisfaction of the nurses will increase and will lead them to perform better. So the results shows hypotheses $9 \& 10$ are accepted.

Table 14. Job Satisfaction and Job Performance Model Summary

\begin{tabular}{|l|l|l|l|l|l|}
\hline $\mathrm{R}$ & $\mathrm{R}^{2}$ & $\mathrm{~F}$ & $\mathrm{Df} 1$ & $\mathrm{Df} 2$ & $\mathrm{p}$ \\
\hline 0.735 & 0.540 & 185.393 & 1 & 158 & 0.000 \\
\hline
\end{tabular}

The results shows a significant positive correlation between nurses' job satisfaction and job performance $\left(\beta=.735, \mathrm{R}^{2}=54 \%, \mathrm{p}<0.05\right)$. If nurses are satisfied with their job the quality of their service will increase. So our final hypotheses 11 is accepted as well.

The purpose of this research is to find out the relationship of contributing factors (pay, human resource management practice, working environment, motivation, promotion) with nurses' job satisfaction and job performance. Regression analysis examined these relationships.

First and second hypotheses determined that pay is positively related with both job performance and job satisfaction of the nurses. Correlation and regression analysis confirmed significant positive correlations. It shows that higher pay can increase the job satisfaction $\left(\beta=.528, R^{2}=28 \%, p<0.05\right)$ and improve the job performance $\left(\beta=.785, R^{2}\right.$ 
$=62 \%, \mathrm{p}<0.05)$ of the employees which is also supported by previous studies (Judge et al., 2010; Lazear, 2000; McCausland et al., 2005; Paarsch \& Shearer, 2000).

Hypotheses 3 and 4 were tested and accepted through correlation and regression analysis. The result confirmed HRMP has a strong positive correlation with job satisfaction $\left(\beta=.552, \mathrm{R}^{2}=30 \%, \mathrm{p}<0.05\right)$ and job performance $\left(\beta=.728, \mathrm{R}^{2}=53 \%\right.$, $\mathrm{p}<0.05$ ). The result of the present study is consistent with the research of (Campbell et al., 2013; Carlson et al., 2011; Kossek et al., 2011).

Results confirmed that hypotheses $5 \& 6$ is accepted and working environment is strongly correlated with nurses' job satisfaction $\left(\beta=.931, \mathrm{R}^{2}=86 \%, \mathrm{p}<0.05\right)$ as well as job performance $\left(\beta=.806, \mathrm{R}^{2}=64 \%, \mathrm{p}<0.05\right)$. Several previous studies found the similar results (Jain \& Kaur, 2014; Shalley et al., 2000). The premises of hypotheses 7 $\& 8$ was that motivation would affect the level of job satisfaction and performance of the nurses. Results confirmed that motivation has a significant positive correlation with nurses' job satisfaction $\left(\beta=.742, \mathrm{R}^{2}=55 \%, \mathrm{p}<0.05\right)$ and job performance $\left(\beta=.936, \mathrm{R}^{2}\right.$ $=87 \%, \mathrm{p}<0.05)$. Previous studies also support this findings (J. N. Baron \& Kreps, 1999; Caligiuri et al., 2010; Pfeffer \& Villeneuve, 1994).

Hypotheses $9 \& 10$ are about how promotion is correlated with job satisfaction and job performance. Study shows that promotion has a significant positive correlation with job satisfaction $\left(\beta=.729, R^{2}=53 \%, p<0.05\right)$ as well as job performance $\left(\beta=.849, R^{2}=\right.$ $72 \%, \mathrm{p}<0.05)$. The result is consistent with the research done by McCausland and others (2005) (McCausland et al., 2005).

Final hypotheses determined the relationship between job satisfaction and job performance. It shows that job satisfaction has significant positive correlation with job performance $\left(\beta=.735, \mathrm{R}^{2}=54 \%, \mathrm{p}<0.05\right)$ of the nurses in the private hospitals in Bangladesh. This findings were well supported by previous studies (Cranny et al., 1992; Steinhaus \& Perry, 1996; Weiss, 2002).

\section{Conclusion}

Current research explores the relationship between the factors (pay, human resource management practice, working environment, motivation, promotion) with job satisfaction and job performance of the nurses of private hospitals in Bangladesh. The model of this research identifies how much influence of above mentioned factors have on the nurses' job satisfaction as well as their job performance which could contribute a lot to the healthcare sector of Bangladesh as well as to the world in improving the service quality of the nurses and reduce turnover. Both private and public hospitals/healthcare institute can design favorable policy for the healthcare staffs 
especially for the nurses to increase the satisfaction of their employees which ultimately will lead to better service and can satisfy their customers (patients).

\section{Study Limitations and Implication for Future Research}

The study is based on correlation and regression analysis, and it has some natural limitation. The analysis only includes given variable and doesn't consider the effect of other variables. The hypotheses comprised in this research focus on individual cognition, perception and attitudes. The study is conducted on the nurses $(n=160)$ of the private healthcare of Bangladesh and future study could re-examine the expressed relationship on public healthcare institutions or new variables could be examine to find the relationship. This study is a vital step towards findings relationship between the factors and job satisfaction of private healthcare institution in Bangladesh as no previous study has been found on the similar area in Bangladesh.

\section{Disclosure statement}

No potential conflict of interest was reported by the authors.

\section{Contact Information}

E-mail: mohammadq@yahoo.com 


\section{References and notes:}

Baron, H., Henley, S., McGibbon, A., \& McCarthy, T. (2002). Motivation questionnaire manual and user's guide. Sussex: Saville and Holdsworth Limited.

Baron, J. N., \& Kreps, D. M. (1999). Consistent human resource practices. California Management Review, 41(3).

Bovier, P. A., \& Perneger, T. V. (2003). Predictors of work satisfaction among physicians. The European Journal of Public Health, 13(4), pp.299-305.

Caligiuri, P., Lepak, D., \& Bonache, J. (2010). Managing the global workforce: John Wiley \& Sons.

Campbell, N. S., Perry, S. J., Maertz Jr, C. P., Allen, D. G., \& Griffeth, R. W. (2013). All you need is... resources: The effects of justice and support on burnout and turnover. Human Relations, 66(6), pp.759-782.

Carlson, D. S., Ferguson, M., Kacmar, K. M., Grzywacz, J. G., \& Whitten, D. (2011). Pay it forward: The positive crossover effects of supervisor work-family enrichment. Journal of management, 37(3), pp.770-789.

Cheng Lim, P., Tang, N. K., \& Jackson, P. M. (1999). An innovative framework for health care performance measurement. Managing Service Quality: An International Journal, 9(6), pp.423-433.

Cranny, C. J., Smith, P. C., \& Stone, E. F. (1992). Job satisfaction: How people feel about their jobs and how it affects their performance: Lexington Books.

Diriwächter, P., \& Shvartsman, E. (2018). The anticipation and adaptation effects of intra-and interpersonal wage changes on job satisfaction. Journal of Economic Behavior \& Organization, 146, pp.116-140.

Downey-Ennis, K., \& Harrington, D. (2002). Organisational effectiveness in Irish health-care organisations. Managing Service Quality: An International Journal, 12(5), pp.316322.

Fisher, C. D. (2000). Mood and emotions while working: missing pieces of job satisfaction? Journal of Organizational Behavior: The International Journal of Industrial, Occupational and Organizational Psychology and Behavior, 21(2),pp. 185-202.

George, D., \& Mallery, P. (2010). SPSS for Windows step by step: A simple guide and reference, 17.0 update: Boston: Pearson.

Gray-Toft, P., \& Anderson, J. G. (1985). Organizational stress in the hospital: development of a model for diagnosis and prediction. Health Services Research, 19(6 Pt 1), p.753.

Griffeth, R. W., Hom, P. W., \& Gaertner, S. (2000). A meta-analysis of antecedents and correlates of employee turnover: Update, moderator tests, and research implications for the next millennium. Journal of management, 26(3),pp. 463-488.

Haas, J. S., Cook, E. F., Puopolo, A. L., Burstin, H. R., Cleary, P. D., \& Brennan, T. A. (2000). Is the professional satisfaction of general internists associated with patient satisfaction? Journal of general internal medicine, 15(2), pp.122-128.

Hackett, R. D., \& Guion, R. M. (1985). A reevaluation of the absenteeism-job satisfaction relationship. Organizational behavior and human decision processes, 35(3), pp.340-381.

Hofstede, H. Minkov (2010) Hofstede, G., Hofstede, GJ, \& Minkov, M.(2010). Cultures and organizations: Software of the mind: New York, NY: McGraw-Hill.[Google Scholar].

Jain, R., \& Kaur, S. (2014). Impact of work environment on job satisfaction. International Journal of Scientific and Research Publications, 4(1), pp.1-8.

Janicijevic, I., Seke, K., Djokovic, A., \& Filipovic, T. (2013). Healthcare workers satisfaction and patient satisfaction-where is the linkage? Hippokratia, 17(2), p.157. 
Jenkins Jr, G. D., Mitra, A., Gupta, N., \& Shaw, J. D. (1998). Are financial incentives related to performance? A meta-analytic review of empirical research. Journal of Applied Psychology, 83(5), p.777.

Judge, T. A., Piccolo, R. F., Podsakoff, N. P., Shaw, J. C., \& Rich, B. L. (2010). The relationship between pay and job satisfaction: A meta-analysis of the literature. Journal of Vocational Behavior, 77(2), pp.157-167.

Judge, T. A., Thoresen, C. J., Bono, J. E., \& Patton, G. K. (2001). The job satisfaction-job performance relationship: A qualitative and quantitative review. Psychological bulletin, 127(3),p. 376.

Kehoe, R. R., \& Wright, P. M. (2013). The impact of high-performance human resource practices on employees' attitudes and behaviors. Journal of management, 39(2), pp.366-391.

Kerschen, A. M., Armstrong, E. P., \& Hillman, T. N. (2006). Job satisfaction among staff, clinical, and integrated hospital pharmacists. Journal of Pharmacy Practice, 19(5), pp.306-312.

Kivimäki, M., Kalimo, R., \& Lindstrom, K. (1994). Contributors to satisfaction with management in hospital wards. Journal of Nursing Management, 2(5), pp.229-234.

Kossek, E. E., Baltes, B. B., \& Matthews, R. A. (2011). How work-family research can finally have an impact in organizations. Industrial and organizational psychology, 4(3), pp.352-369.

Lazear, E. P. (1986). Salaries and piece rates. Journal of business, pp.405-431.

Lazear, E. P. (2000). Performance pay and productivity. American Economic Review, 90(5), pp.1346-1361.

Lochman, J. E. (1983). Factors related to patients' satisfaction with their medical care. Journal of community health, 9(2), pp.91-109.

Locke, E. A. (1969). What is job satisfaction? Organizational behavior and human performance, 4(4), pp.309-336.

McCausland, W. D., Pouliakas, K., \& Theodossiou, I. (2005). Some are punished and some are rewarded: A study of the impact of performance pay on job satisfaction. International Journal of Manpower, 26(7/8), pp.636-659.

Meltz, N. M., \& Marzetti, J. (1988). The shortage of registered nurses: An analysis in a labour market context: Registered Nurses' Association of Ontario.

Moen, E. R., \& Rosen, A. (2005). Performance pay and adverse selection. Scandinavian Journal of Economics, 107(2),pp. 279-298.

Mueller, C. W., \& Price, J. L. (1990). Economic, psychological, and sociological determinants of voluntary turnover. Journal of behavioral economics, 19(3), pp.321-335.

Nabirye, R. C., Brown, K. C., Pryor, E. R., \& Maples, E. H. (2011). Occupational stress, job satisfaction and job performance among hospital nurses in Kampala, Uganda. Journal of Nursing Management, 19(6),pp. 760-768.

Nasurdin, A. M., Ramayah, T., \& Osman, M. (2006). Job Satisfaction and Organizational Commitment among the Malaysian Workforce: Malaysian Publications: April.

Oettinger, G. S. (2001). Do piece rates influence effort choices? Evidence from stadium vendors. Economics Letters, 73(1), pp.117-123.

Organ, D. W., \& Ryan, K. (1995). A meta-analytic review of attitudinal and dispositional predictors of organizational citizenship behavior. Personnel psychology, 48(4), pp.775-802.

Organization, W. H. (2017). Together on the road to universal health coverage: A call to action.

Paarsch, H. J., \& Shearer, B. (2000). Piece rates, fixed wages, and incentive effects: Statistical evidence from payroll records. International Economic Review, 41(1), pp.59-92.

Pfeffer, J., \& Villeneuve, F. (1994). Competitive advantage through people: Unleashing the power of the work force (Vol. 61): Harvard Business School Press Boston, MA.

Pincus, J. D. (1986). Communication satisfaction, job satisfaction, and job performance. Human communication research, 12(3), pp.395-419. 
Podsakoff, P. M., \& Williams, L. J. (1986). The relationship between job performance and job satisfaction. Generalizing from laboratory to field settings, 207,p. 253.

Roodt, G., Rieger, H., \& Sempane, M. (2002). Job satisfaction in relation to organisational culture. SA Journal of industrial Psychology, 28(2),pp. 23-30.

Rubin, A., \& Babbie, E. (2005). Research Methods for Social Work. ; Thomson Learning. Inc. United States of America.

Ruiz-Lozano, M., \& Nieto, R. R. (2016). Ethics and Corporate Social Responsibility in Human Resource Management Strategic Labor Relations Management in Modern Organizations (pp. 135-148): IGI Global.

Saridakis, G., Muñoz Torres, R., \& Johnstone, S. (2013). Do Human Resource Practices Enhance Organizational Commitment in SME s with Low Employee Satisfaction? British Journal of Management, 24(3), pp.445-458.

Schultz, K. L., Juran, D. C., Boudreau, J. W., McClain, J. O., \& Thomas, L. J. (1998). Modeling and worker motivation in JIT production systems. Management Science, 44(12part-1), pp.1595-1607.

Seyed Javadin, R. (2002). Basics and applications of human resource management and personnel. Tehran: look for knowledge,p. 161.

Shalley, C. E., Gilson, L. L., \& Blum, T. C. (2000). Matching creativity requirements and the work environment: Effects on satisfaction and intentions to leave. Academy of management journal, 43(2), pp.215-223.

Smith, P. C., \& Forgione, D. A. (2007). Global Outsourcing of Healthcare: A Medical Tourism Decision Model. Journal of Information Technology Case and Application Research, 9(3), 19-30. doi: 10.1080/15228053.2007.10856117

Steinhaus, C. S., \& Perry, J. L. (1996). Organizational commitment: Does sector matter? Public Productivity \& Management Review, pp.278-288.

Van Niekerk, W. (1987). Eietydse bestuur: Butterworth.

Verschuren, P., \& Masselink, H. (1997). Role concepts and expectations of physicians and nurses in hospitals. Social science \& medicine, 45(7), pp.1135-1138.

Weiss, H. M. (2002). Deconstructing job satisfaction: Separating evaluations, beliefs and affective experiences. Human resource management review, 12(2), pp.173-194.

Wu, M.-Y., \& Lee, Y.-R. (2011). The effects of internal marketing, job satisfaction and service attitude on job performance among high-tech firm. African Journal of Business Management, 5(32), pp.12551-12562. 